\title{
The educational aspects of ethics
}

\author{
Dorota Probucka
}

\begin{abstract}
The purpose of my article is to show the importance of normative ethics for the education of young people in three areas: individual, social and natural. In the first case, ethics answers the question how we should treat ourselves. Thus, it teaches responsibility for oneself, for one's life and individual development. In the second case, ethics answers the question how we should treat other people in order to minimize the risk of harming them. Thus, it teaches responsibility to other members of society. In the third case, normative ethics reminds us of moral obligations towards non-human beings, stressing that suffering has an interspecies character, and doesn't pertain only to representatives of Homo sapiens.
\end{abstract}

Keywords: morality, value, education, normative ethics, humanity

The main theme of the article is to explain the importance of ethics for the education of young people. Teaching ethics should relate primarily to the transfer of knowledge in the field of normative ethics, which nowadays has been, unfortunately, degraded as unscientific, and thus unworthy of promotion. But normative ethics does not pursue cognitive goals, as do the natural sciences. It doesn't answer the question what the world is like, and with what methods we should explore it, because it doesn't deal with the realm of facts available to empirical knowledge and science. Normative ethics plays a different role, which is equally important for human life, and which involves the search for patterns for morally right conduct. Thus, it organizes the lives of young people in axiological-normative terms. By asking what we should strive for, how we should behave, how we should evaluate one's own and others' actions, ethics teaches us to look at life through the perspective of norms and moral values. It teaches duties and responsibilities. While fulfilling an advisory function in life, it doesn't relieve young people from rational activity, because every man needs to individually consider and accept the criteria for morally right conduct, and recognize them as their own. And that is why this kind of knowledge of life is as important in the process of teaching as scientific knowledge.

\section{The importance of ethical education in individual aspect}

In the individual dimension, young people should engage in ethical considerations in order to find the axiological basis for the development of their own humanity. A classic example of this would be the attitude of the father of ethics - Socrates, who taught his disciples honest thinking and honest life (Heller, 1995, p. 13). Socrates was one of the first people in our culture to have understood the importance of ethical education of young people, the need to develop the moral dimension of human thinking and the associated moral dimension of conduct. Socrates called this ability virtue, or moral courage, which today is one of the fundamental concepts of our culture. The philosopher equated virtue with knowledge of a particular type, the knowledge of the moral good, which can be reached by activating one's own reason. This means that the moral dimension of our actions is not possible if there is no critical reflection on our existing views, and the beliefs professed by others. Only then can we advance towards the objective truth about what is good, honest and just. And this knowledge, hopes Socrates, will change our lives, making it wiser, more conscious and reflective. The Socratic concept of basing ethical education on thought, intellectual reflection on the good, is 
the basis of many schools of ethics today. Let us emphasize, taking this path is an essential condition for the moral development of young people, because it is on their conscious intellectual effort, on their thinking and actions that it depends whether they will overcome their life inertia and attempt internal development, being more fully human, or activating their humanity (Gauthier, 1997, pp. 339-346). After all, man is not who he is, but what he can become. This sentence expresses the hope ethicists have in the growth opportunities of the representatives of the human species, not in the biological sense, but in the spiritual, axiological. Let us keep in mind that in European culture, the teaching of ethics has never severed its bond with the ancient Greek concept of paideia - the theory of education, for which the starting point was not the human being with its current beliefs, judgements, preferences - but the idea of humanity, into which the being should grow. Let us quote here the words of the Polish philosopher, Michał Heller: "It is in all of us, both in the teacher and student, that a conscious intellectual effort should be made. As a result, we gain inner awareness, whether a decision should be taken, or not. In the former case, a difficult road awaits us, often called the climbing. Its outcome depends on our perseverance and the amount of work involved in shaping oneself. If we decline this decision, or refuse to begin to realize it, we condemn ourselves to a descending path in advance. In this case, our consciousness gives up its capabilities and voluntarily subjects itself to the inertia of matter, with which it is united" (Heller, 1995, p. 76).

Therefore, what would the student's development effort be from the ethical perspective? The answer is complex and requires analysing of several issues. Let us recall that selfimprovement should cover three dimensions: individual, social and natural. In the individual dimension, the postulate of self-improvement is based on recognizing oneself as value. Each of us is unique and even because of this fact, our existence requires respect. A moral life begins when a young person begins to protect their dignity, when they realize that they are something that others can manipulate and use. The importance of Kant's second formulation of the categorical imperative should be emphasised here: "Act in such a way that you treat humanity, whether in your own person or in the person of any other, never merely as a means to an end, but always at the same time as an end" (Kant, 1999, p. 62). Hence, the Kantian thesis that man is not a thing should be considered as a basis for self-improvement. Thus, ethical education should be started from the practice of self-affirmation. Man should fall in love with one's own life, consider it as valuable, worthy of care and respect. Very often young people are raised with low self-esteem, with the tendency to understate their own value and underestimate their own abilities. A young man's enemy is an unconscious aversion to himself and the conviction of not deserving that which is good in the world. The idea of selfaffirmation is expressed by the basic principle of Christian ethics - love your neighbour as yourself. Therefore, if to love another human being is a virtue, it also must be a virtue to love oneself as a human being. It is therefore necessary to begin changing relationships with other people from changing the attitude towards oneself. Recognizing oneself as value - this is the fundamental principle of normative ethics (Audi, 1997, p. 78). Let us emphasize that teaching young people to respect themselves does not exclude respect for other people. On the contrary, it determines it. Caring for oneself doesn't necessarily have to rely on the use of other people in achieving one's own goals. Anyone who cares about their health, development and well-being is not selfish. On the other hand, an egoist is one who, filled with unconscious aversion to the world, turns away from people without giving them support and assistance (Nussbaum, 1990, p. 167). This attitude is not related to self-respect, for egoists treat people as objects and their behaviour is marked by hostility and contempt for life in general, and for themselves in particular. This is because each one of us unconsciously projects one's own attitude towards oneself onto relationships with others. 
The second determinant of moral development in the individual dimension is the so called being in the truth. Normative ethics emphasizes the important role of truth understood as a moral value that organizes our lives and interpersonal relationships, and truthfulness, which is consciously speaking true statements (Slote, 1995, p. 98). First of all, everyone should know what the truth is. This knowledge and the pursuit of that value would determine the degree of intellectual and psychological integrity and would be the prerequisite for the authenticity of our existence. So what does it mean to be in the truth? It is honesty towards oneself, linked with the desire to purify one's mind from negative perceptions about oneself, superstitions, prejudice, mental stereotypes, false assumptions and fears. Being in the truth is the opposite of mindless submission to externally imposed schemes of thinking and acting. A man who has not been taught the pursuit of truth will easily accept a false image of himself and the surrounding reality. He will live on illusions about himself, about other people and the world. And in practice, this means increased susceptibility to various forms of manipulation and lies. For consent to a lie is tacit consent to the reification of man, to bringing his value down to that, which is utilitarian and consumerist (Hudson, 1986, p. 57).

In ancient Greek ethics, truth was defined by the word aletheia, which meant unconcealedness. Thus, being in the truth should be understood as disclosure, exposing what is hidden, pent-up, repressed in our nature. In addition, the demand for unconcealedness needs to be understood as coherence occurring between our thoughts and words, and coherence between words and deeds. The importance of ethics in education would consist, therefore, of learning such a way of life in which spoken words are a reflection of the inner beliefs, and actions are a confirmation of the previously spoken declaration. Unconcealedness is, in this case, the unity of thought, word and deed (Anton, 1980, pp. 49-60).

It should also be emphasized that the ethical postulate of the pursuit of truth, understood as the absence of conflict between thought, word and deed, indicates the progressive process of humanization, for orientation really makes our life more human. On the other hand, turning away from the truth leads to hypocrisy understood as a way of life. A hypocrite is not just a liar; it is one, who lost the ability to distinguish truth from falsehood, and hypocrisy could be interpreted as a special case of an individual or a collective disease (Margolis, 1966, p. 98). In the social dimension, it would destroy the spiritual dimension of culture, questioning the meaning of rules and values. In the individual dimension, it would mean a disease of the soul, understood as a moral and cognitive dissonance. Let us recall here the words contained in the manual of ethics by two American philosophers, Peter Vardy and Paul Grosch: "Living in truth is perhaps the highest value, which man can achieve, and will always be a challenge to the existing order: the society in which we live, a religious group, to which we belong, a political system which wants to speak on our behalf. Truth can't be closed within any group, as it always makes a break to freedom to shed light in the gloomy darkness of the world" (Vardy \& Grosch, 2015, p. 217).

Recalling again the position of Socrates, who compared the mission of an ethics teacher to a bittern, a drone the released by the gods. He should intellectually bite his disciples, so that they won't fall into a state of axiological torpor, devoid of ethical demands, aspirations, selfimprovement, and basing one's actions on habituation, blind habit and the pressure of the environment (May, 1997, pp. 37-50). Worth quoting here are the words placed above the entrance to the house of the Krakow chronicler, Jan Dlugosz, "There is nothing better than a good mind (bona mens)". Here is a basic goal of the teaching of ethics to the youth. He should be educated in such a way to develop in him the so called good mind, i.e. one that will serve more than individual and particular goals, one that will neither be instrumentalized, nor intimidated, one that will not manipulate others and will not agree to manipulation. It is a mind that has bound its thinking with the good. 


\section{The importance of ethical education in the social aspect}

Let us move on to the next question, as ethical education is not just about the development of the intellectual and volitional sphere of young people. Ethics should also cultivate their sensitivity, natural capability for empathy, for sensing the physical and mental condition of others as a lack of concern for the emotional dimension of moral life leads to indifference to other people's suffering and to the material and instrumental treatment of others moving on, here, to the social aspect of the teaching of ethics, based on a sense of community with other people. First of all, the legal and moral rules applicable in society are not the same in scope as moral rules. Legal rules are the ethical minimum that organizes only basic human relationships. On the other hand, moral rules do not apply to what is most important in ethics - to injustice and the postulate of its minimization. Suffering, human harm includes an appeal, a request for help, and therefore its minimization is a basic postulate from the moral point of view. And the question how to act so that others don't suffer because of us should be the main objective of ethical considerations (Jopling, 1998, pp. 100-112). Therefore, practical ethics should be developed, as it helps to harmonize interpersonal relationships and works beyond world view, religious and political differences. Such ethics should pay special attention to two rules: first - the postulate of reducing suffering, and second - guarding human dignity and thus prohibiting the manipulation of others to pursue one's own interests. These two rules are a special case of the principle of universalization. This principle seeks to generalize the attitudes that we have towards ourselves to other people. It is the effort of universalization that would especially indicate the development of moral awareness. Hence, through the use of appropriate arguments, one should make people aware of the necessity of this principle in social life. It is adherence to this principle that brings us out from the collective chaos and barbarism.

\section{The importance of ethical education in the natural aspect}

Now let us ask the question about the importance of ethics in the natural sense, going beyond the individual and social dimension, and including the world of non-human beings. Environmental ethics advises that man has a moral obligation not only towards oneself, other people, but also to other sentient beings. For what unites us with other representatives of the natural world (especially vertebrates) is unity in experiencing pain. Man is not only an intelligent being, but it is also a living organism capable of experiencing pain. And it is his carnal nature that is his connection to other living beings. Moreover, all organisms are evolutionarily related to each other, since one species emerged from the other. In this respect, man is a continuation of the lower forms of life, and without them the evolution of his existence would not be possible. Ethicists are asking the question whether man is free to interfere with the natural environment, whether he can freely kill and cruelly treat other living beings only because he now occupies the highest, though certainly not the ultimate, place in the development of life on Earth? And the answer is: "There once had to be a moment when thinking was ripe for protesting against the accepted merciless treatment of other living beings and demanding from ethics also to have mercy on them. Ethics is the infinitely extended responsibility for everything that lives" (Schweitzer, 1987, p. 85).

The promotion of environmental ethics is particularly important these days. Its main task should be to modify traditional human thinking about anthropocentric nature because only by changing human mentality we will be able to reduce the devastation of nature, restrain the devastating tendencies of man and minimize the instrumental, objective treatment of animals. It is modern ethics that should disclose the source of this so-called speciesism, inherent in certain points of the Judeo-Christian tradition, in Cartesian-Newtonian mechanicism, liberal individualism, and American pragmatism. Where does the devastating impact of these thought patterns of life on the biosphere come from? The Judeo-Christian tradition has set man over 
nature, proclaiming that it was created solely for his benefit and rule. On the other hand, Cartesian-Newtonian mechanicism, which significantly shaped the mentality of modern times, treated the world as machinery. Animals were classified as animate mechanisms, which man could use for his own purposes without any moral scruples. On the other hand, the individualism of the Enlightenment, which reached its apogee in the theory of liberalism, erased the notion of the human community and the community of all living beings, i.e. the good of the whole ecosystem. Nature was to serve only as a means to satisfy the individual, its personal needs. On the other hand, American pragmatism, associated with liberal thinking, introduced the pattern of so-called instrumental rationality. In it, everything must serve man's purposes, which are all devoid of inherent value.

However, describing and analysing negative thought structures, enhancing the destructive tendencies of man against nature and cruelty to animals is not the only goal of environmental ethics. It should be in the process of education that students are made to realize that man is just one of many living beings inhabiting the Earth, that he is one of the links in the evolutionary chain of the development of life, in which all cells are equal, necessary and related to each other (Devall \& Sessions, 1985, p. 96). Let us recall here the words of the spiritual father of environmental ethics, Albert Schweitzer: "Man is life that wants to live in the midst of other life that wants to live. Therefore, I need to respect life" (Schweitzer, 2009, p. 111). It is ethics that should form an ecological view of the world; it should remind one of the fundamental harmony of all living creatures, each of which demands respect. Thus, the main principle of environmental ethics should be: "Life should not be destroyed, apart from rigorously determined, biological necessity" (Lazari-Pawłowska, 1992, p. 390). In this case, education would be based on a well thought-out educational practice, which shapes both the culture of feelings and the culture of thinking about nature. Concern about the culture of feelings would be based on stimulating sensitivity to the fate of other living beings, especially animals, and on nurturing compassion and natural impulses of the heart. Concern about the culture of thinking would be based on a clear recognition of acts that cause animal suffering as morally repugnant and unworthy of man. Therefore, the second postulate of environmental ethics should read - an animal is not a thing. It is not an object, a commodity, a raw material serving the accomplishing of human interests. It is a living and sensitive being, capable of suffering, with needs that man should respect. Let us refer again to the words of Albert Schweitzer: "Where we are, let there be as much relief in pain, cruelty, wanton destruction or killing as we possibly can achieve" (Schweitzer, 1987, p. 309).

The aim of environmental ethics should therefore be to create a new ethos of a good human host of the Earth. At the present stage of evolution, it is man that has the most developed consciousness and intelligence, and the greatest potential for action. The being of the highest intelligence should take over the functions of the host and caretaker for nature, not solely for their own benefit, but for the good of the entire biosphere, since the higher level of intelligence, the higher the level of responsibility for one's actions (Montefiore, 1970, p. 55). In this case, ethical education should promote so-called ecological thinking, according to which the work on the development of one's own humanity would not be possible without reference to the wider natural context. It is thinking in terms of belonging to a wider agenda that entails a sense of responsibility for the environment and changes the way human activities are valued. Thus, moral good would be associated only with those actions that do not harm people and the whole natural world (Norton, 1984, pp. 131-148).

\section{Conclusion}

The teaching of ethics is a process of expanding and increasing moral consciousness, which also is identical with our humanization. In the present article it has been attempted to show that the process of development of moral consciousness should be implemented in three areas: 
individual, social and natural. Each of these three areas is related to a certain set of values and duties: to oneself, to other people, and to other beings who are suffering. Knowledge of and respect for these moral obligations should help young people to find valuable life and their humanity.

Dorota Probucka is a professor of ethics at Cracow Pedagogical University. She is the author of numerous articles, three books devoted to ethics and the scientific editor of nine collective works. She was the originator and co-founder of the Polish Society of Ethics.

\section{Corresponding author:}

Dorota Probucka, Cracow Pedagogical University, Podchorążych 2 street, 30-084 Cracow (Poland)

Email: dorotaprobucka@op.pl

\section{References}

AUDI, R. (1997): Moral knowledge and Ethical Character. Oxford: Oxford University Press. ANTON, J. P. (1980): Dialectic and Health in Plato's Gorgias. In: Ancient Philosophy, 1(1), pp. 49-60.

DEVALL, B. \& SESSIONS, G. (1985): Deep Ecology: Living as if Nature Mattered. Salt Lake City: Peregrine Smith.

GAUTHIER, C. C. (1997): Teaching the Virtues. In: Cambridge Quart Healthcare Ethics, 6(3), pp. 339-346.

HELLER, M. (1995): Usprawiedliwienie wszechświata [Justification of the Universe]. Kraków: Znak.

HUDSON, S. D. (1986): Human Character and Morality. New York: Routledge.

JOPLING, D. A. (1998): First Do Not Harm: Over Philosophising and Pseudo-Philosophizing in Philosophical Counselling. In: Inquiry, 17(3), pp. 100-112.

KANT, I. (1999): Grundlegung zur Metaphysik der Sitten. Hamburg: Meiner.

LAZARI-PAWŁOWSKA, I. (1992): Etyka [Ethics]. Wrocław: Ossolineum

MAY, H. E. (1997): Socratic Ignorance and the Therapeutic Aim of the Elenchos. In: Apeiron: A Journal for Ancient Philosophy and Science, 30(4), pp. 37-50.

MARGOLIS, J. (1966): Psychotherapy and Morality: A Study of Two Concept. New York: Routledge.

MONTEFIORE, H. (1970): Can Man Survive? The Question Mark and Other Essays. London: Fontana.

NORTON, B. G. (1984): Environmental Ethics and Week Anthropocentrism. In: Environmental Ethics, 6(2), pp. 131-148.

NUSSBAUM, M. C. (1990): Love's Knowledge. Oxford: Oxford University Press.

SCHWEITZER, A. (2009): Die Ehrfurcht vor dem Leben. Munchen: C. H. Beck Verlag.

SCHWEITZER, A. (1987): Philosophy of Civilization: Culture and Ethics, transl. C. L. Campion. New York: Prometheus

SLOTE, M. (1995): From Morality to Virtues. Oxford: Oxford University Press. VARDY, P. \& GROSCH, P. (2015): The Puzzle of Ethics. New York: Routledge. 